\section{Kastamonu Eğitim Dergisi Kastamonu Education Journal}

Temmuz 2019 Cilt:27 Sayı:4

kefdergi.kastamonu.edu.tr
Başvuru Tarihi/Received: 3.10.2018

Kabul Tarihi/Accepted: 29.01.2019

DOI: $10.24106 /$ kefdergi.3376

\title{
Felsefe Lisans Eğitiminin Öğrencilerin Özel ve Profesyonel Yaşamına Katkısı: Kastamonu Üniversitesi Felsefe Bölümü Örneği ${ }^{1}$
}

\section{Philosophy's Contribution to Students Private and Professional Lives}

\section{Öz}

\author{
Sibel KIBAR ${ }^{2}$
}

Bu çalışma Kastamonu Üniversitesi Felsefe Bölümü’nden mezun olmuş olan öğrencilerin bu programda almış oldukları öğrenimin onların kişisel ve mesleki yaşamlarına katkısını anlamayı amaçlamaktadır. Çalışma, ulaşılabilen ve görüşmeyi kabul eden mezunların tamamıyla yapılmıştır (2013, 2014 ve 2015 yıllarında mezun olan 110 mezunun 77'siyle, \%70 oranında). Bu görüşmelerde, felsefe okumuş olmanın mezunların kişisel ve profesyonel yaşamlarına, olumlu veya olumsuz etkileri olup olmadığını anlamaya yönelik yirmi beş açık uçlu soru sorulmuştur. Mezunların çoğu iş arama sürecinde karşılaştıkları zorluklardan yakınmaktadırlar. Ancak özel sektörde iş arayıp da bulamayanların oranı görece düşüktür. Felsefe bölümü mezunlarının iş bulma sürecinde yaşadıkları zorluklar, Fen Edebiyat Fakültelerinin diğer bölümlerinin mezunlarının istihdamından ayrı düşünülmez. Çalışmanın ortaya koyduğu üzere, felsefe bölümü mezunları çalıştıkları işlerde başarılı ve aranan birer eleman olmuşlardır. Bu araştırma "bir mesleğin dar sınırları içine kapatılmayan zihinlerin" de kişisel ve mesleki yaşantılarında, başarılı olacağı varsayımını doğrulamıştır.

Anahtar Kelimeler: Felsefe lisans eğitimi, felsefe mezunlarının istihdam sorunu, felsefenin işlevi, felsefe bölümlerinin sorunları

\section{Abstract}

This study aims to understand the contribution of philosophy program of Kastamonu University's Department of Philosophy to philosophy graduates' private and professional lives. The study was conducted with all of the graduates who could be reached and accepted the interview (77 of 110 graduates in total who graduated in 2013, 2014 and 2015, equals to 70\%). This interview consists of twenty five questions in order to understand if earning a philosophy major degree has advantages or disadvantages in their both private and professional lives. Most graduates complain about the difficulties they face during the job hunting processes. However, the percentage of those who cannot find a job in the private sector is relatively low. Difficulties, being experienced by the graduates of the department of philosophy, cannot be considered separate from the employment of the graduates of other departments in the Faculty of Arts and Sciences. As the study suggests, the graduates of philosophy department have been successful and preferred staff in their jobs. This study has confirmed the assumption that "minds that are not limited within the narrow boundaries of a profession" can be successful in their private and professional lives.

Keywords: Philosophy undergraduate program, philosophy major's employment problem, function of philosophy, problems of philosophy graduates. 


\section{Extended Abstract}

Introduction: This study aims to understand the contribution of philosophy program of Kastamonu University's Department of Philosophy to philosophy graduates' private and professional lives. It is known that in our society some people have negative attitudes towards bachelor degree in philosophy programs. This study takes the aim to break these negative attitudes and prejudices. When students enter into philosophy department whether they have chosen deliberately or not, it can easily be seen that they all have anxiety for now and their futures. They all complain about such questions as: "What philosophers do?", "What is the use of philosophy programs?" They demand convincing answers to these pejorative questions from their teachers. Since there is no definitive output of philosophy programs and there is no exact vocation for philosophy majors, most students are in a pessimist mood. They expect to be directed towards some professional sectors by their teachers before they are graduated. This study intends to feel comfort on these issues both students and teachers with collecting real data. A similar study has been never done in Turkey before. So, this study conducted in Kastamonu University will be a significant contribution to the literature. And, philosophy students and graduates will have the chance to learn what their friends do, how they improved themselves when they were studying philosophy, how much they are gained from the program; and so, they can empower themselves through others' experiences.

Method: The study is conducted with all the graduates between the years 2013-2015 who are willing to participate through phone calls. Within the scope of this study, one to one in-depth interviews are held with Kastamonu University's philosophy bachelor program graduates. In total, 77 interviews have done which equals to $70 \%$ of the 110 graduates. This interview consists of twenty five questions in order to understand if being a philosophy major has advantages or disadvantages in the graduates' both private and professional lives. These questions are designed with the help of major philosophy professors' reports and interviews. The analysis of qualitative data is done through inductive analysis and descriptive analysis. And, those findings are compared with the oservations and reports of the philosophy proffessors.

Findings: It is assumed that the minds which are not limited via a vocational education will be more successful in private and professional lives compared to ones having a vocational education since philosophy graduates owing to their education have some abilities such as observation, vision, perception, understanding, evaluation, solving problems, being open minded, questioning, analytical thinking, reasoning and justifying decisions. With the help of these abilities, they can make themselves ready to gain new skills. These interviews uncovers if philosophy graduates have these skills. Most graduates complain about the difficulties they face during the job hunting processes. However, the percentage of those who cannot find a job in the private sector is relatively low which is $9 \%$. Difficulties, being experienced by the graduates of the department of philosophy, cannot be considered separate from the employment of the graduates of other departments in the Faculty of Arts and Sciences. As the study suggests, the graduates of philosophy department have been successful and preferred staff in their jobs. 


\section{Giriş}

Felsefe, tarihsel olarak temel bilimlerin de temelinde yer alan bir disiplindir. Felsefenin ne işe yaradığı, diğer bilimlere ne tür katkılar sağladığı düşünce tarihi boyunca sıkça sorulmuş bir sorudur ve bu konuda ciltlerce makale ve kitap yazıımıştır. Ancak, felsefe lisans programı okuyan öğrencilerin gündelik yaşamlarına nasıl bir etkisi olduğu sorusuna açık ve seçik bir yanıt verilmemiştir. Uluslararası tanınmış okulların ün yapmış felsefe bölümlerinin örneğin Stanford Üniversitesi Felsefe Bölümünün web sayfalarında, (Standford University Department of Philosophy, "Why Philosophy?") ve yayımladıkları broşürlerde, felsefe bölümünün öğrencilere, eleştirel düşünme, sorgulama, düşüncelerini sistematik bir şekilde ifade etme, yazma ve argümanlara dayandırma gibi beceriler katacağı anlatılmaktadır. Ancak felsefe bölümü mezunlarının mezuniyetlerinin ardından iş bulma süreleri, hangi alanlarda istihdam edildikleri ve eğitimleri sonucunda kazandıkları yetileri profesyonel yaşamlarına aktarıp aktaramadıkları araştırılmamıştır.

Felsefe lisans programları öğrencileri doğrudan bir mesleğe yönlendiren bir eğitim sunmaz. Ülkemizde felsefe bölümü mezunları Milli Eğitim Bakanlığı'nın dönemsel ihtiyaçlarına göre, "pedagojik formasyon” alarak Felsefe Grubu Öğretmeni olabilmektedirler. Bunun dışında doğrudan işaret edilen bir iş alanı veya meslek yoktur. Öğrenciler ilgi alanlarına, kapasitelerine veya çevrelerine göre bir alanda istihdam edilebilmektedirler. Felsefe bölümü, öğrencilere doğrudan bir meslekle ilgili eğitim vermese de, zihin kapasitelerini geliştirici bir öğrenim sunmaktadır. Bu nedenle, belirli bir uzmanlık gerektirmeyen işlerde, firsat tanındığında felsefe bölümü mezunlarının başarılı olabileceği düşünülmektedirler.

Felsefe bölümünün net bir çıktısının olmaması ve doğrudan bir iş alanına işaret etmemesi, öğrencileri çoğunlukla karamsarlı̆ga itmektedir. Önceki mezunların ne yapttkları onlara sunulursa, felsefe bölümüne gelen öğrencilerin iş bulma kaygıları, azaltllabilir. Ayrıca, felsefe bölümü mezunlarının felsefe mezunu olmanın ayrıcalıklarına dair söylediklerinin, felsefe bölümünü tercih etme düşüncesi olan veya hâlihazırda felsefe okuyan öğrencilerde, felsefe disiplinin soyutluğundan duydukları tedirginlikleri hafifletilebilir. Bu çalışmada ortaya konulan veriler, felsefe bölümlerine duyulan güvensizliği gidermeye yöneliktir.

Kastamonu Üniversitesi Felsefe Bölümü ilk mezunlarını 2013 yılında vermiştir. Bu tarihten beri mezun veren ve ikili eğitim yapan Felsefe Bölümü iyi felsefeciler yetiştirmeyi amaçlamanın yanı sıra, İnsan Hakları, Etik, Toplumsal Cinsiyet Eşitliği gibi dersler aracılığıyla, iyi yurttaşlar ve insan haklarına duyarlı insanlar yetiştirmeyi amaçlamaktadır. Lisans eğitimi herkesin yaşamında önemli bir dönemeci oluşturmaktadır. Felsefe bölümü mezunlarının yaşamlarında bu dönemecin yeri, artılarıyla ve eksileriyle araştırılmalıdır.

Diğer disiplinlerden farklı olarak, felsefe disiplinine karşı toplumumuzda negatif bir algı olduğu bilinmektedir. Bu algı çeşitli önyargılardan kaynaklanmaktadır. Bu önyargıların kaynağında elbette felsefenin yeterince bilinmemesi veya yanlış bilinmesi yatmaktadır. Olumsuz önyargıların yanı sıra bir de felsefe okumanın maddi ve manevi bir getirisi olmadığına inanılmaktadır. Felsefe disiplinin soyutluğunun yanı sıra, felsefe lisans programlarının belirli bir iş alanına işaret etmemesi bu inanışı pekiştirmektedir. Öğrenciler lise yıllarından beri felsefeye ilişkin bu olumsuz önyargılara maruz kalmaktadırlar. Üniversitede felsefe okuyan öğrenciler de okudukları dört yıl boyunca, bu önyargılarla boğuşmak zorundadırlar. İster kendi istekleriyle, ister rastgele felsefe bölümünü kazanmış olsunlar, felsefe bölümünde okuyan öğrencilerin yüzlerinden endişe okunabilmektedir. Felsefe bölümündeki hocalarına sordukları sorulardan, toplumdaki önyargıları silebilecek yanıtlar duymayı istemektedirler. Özellikle, mezun olduktan sonra yapabilecekleri işlerin belirgin olmaması, öğrencilerin çoğunun karamsarlığına neden olmaktadır. Hocalarından bu konuda da net yanıtlar duymayı ve bir takım iş alanlarına henüz lisansı bitirmeden yönlendirilmeyi beklemektedirler.

Lisans yıllarına böyle bir karamsar tablo hâkim olsa da, felsefe bölümü mezunlarının diğer pek çok disiplinin lisans programlarından mezun olanlardan daha fazla dezavantaja sahip olmadığı gözlemlenmektedir. Bu gözlem, eski mezunlarla yapılan sistematik olmayan görüşmelere ve kişisel gözlemlere dayanmaktadır. Ayrıca, felsefe lisans programı öğrencilere bir diplomadan daha fazlasını vermektedir. Sistematik düşünme, analiz etme, argümanlara dayalı konuşma ve yazma kabiliyeti kazandırmaktadır. Bu yetilerle felsefe mezunlarının yalnızca kendi istek ve becerilerine uygun işlerde çalışmakla kalmayıp, yaşam karşısında güçlü, saygın ve başarılı bir duruşa sahip olmaları gerektiği düşünülmektedir. Felsefe lisans programında yaşam boyu kendilerine kılavuzluk edecek düşünür ve düşüncelerle tanışıp, karşılaştıkları kişisel zorlukların daha büyük varoluşsal ve yapısal sorunlarla bağlantılı olabileceğini görmüşlerdir. Ayrıca, bölümde aldıkları insan hakları dersi, felsefe bölümü mezunlarını kendi haklarını arayan ve başkalarının haklarına saygılı, iyi birer vatandaş kılmaktadır. Dolayısıyla, felsefe bölümü mezunlarının diğer lisans programlarından mezun olanlardan geleceğe dair daha endişeli ve karamsar olmalarını gerektirecek bir durum olmamalıdır. Çotuksöken'in $(2014,117)$ belirttiği üzere, felsefeye ilişkin toplumdaki önyargının temelinde yatan istihdam sorunu aşabilmek için felsefe eğitiminin öğrencilere kazandırdıkları niteliklerin vurgulanması gerekmektedir. Felsefe eğitimi veya öğrenimi kişilere çevreleriyle 
olan bağlarını anlama ve sorgulama yetisi kazandırır, olayları etik bir süzgeçten geçirmesine yardımcı olur, bu anlamda felsefe "insanlaştırır".

Hal böyleyken, bu gündelik gözlemlerin bilimsel olarak ispat edilmesi gerekmektedir. Felsefe lisans programının felsefe bölümü mezunlarına olumlu katkılarını ya da olumsuz etkilerini ortaya koymayı hedefleyen bir çalışma Türkiye'de yapılmamıştr. Aşağıda felsefe lisans programlarına, üniversitelerdeki felsefe bölümlerine ve felsefe bölümü mezunlarına ilişkin değerlendirmelere yer verilmiştir. Ancak bu değerlendirmeler sistematik ve bilimsel gözlem ve araştırmalara dayanmamaktadır. Bu çalışma, şimdiye kadar yapılan değerlendirmelerin gerçekliğini küçük bir evrende test etmektedir. Yükseköğretimde felsefeye ve felsefe bölümü mezunlarıyla ilgili kimi değerlendirmelerin doğruluğu ispat edilirken, kimi yanlış kanıları çürütmeye dönük nesnel bulgular ortaya konulmuştur. Öncelikle, felsefe lisans programlarına ilişkin genel değerlendirmeler, felsefe bölümlerine, öğrencilere ve mezunlara dair önyargılar literatüre atffla aktarılmıştr. Ardından çalışmanın amacı, soruları ve yöntemi sunulmuştur. Araştırmanın bulgularııın paylaşılmasının ardından felsefe lisans programları ve felsefenin mezunların yaşamlarındaki etkiler bu bulgular ışığında tartışılmaktadır.

\section{Felsefe Lisans Programlarının "İşe Yararlılığı”}

Felsefe lisans programlarının sorularının tartışıldığı ortamlarda, ilk söylenen felsefe okuyanların işsiz kaldığı, felsefenin gündelik yaşamdan kopuk olduğu ve bu nedenle de "işe yaramadığı" iddiasıdır. Bu iddiaların gerçekçi bir temeli vardır zira felsefe çoğu zaman soyut bir disiplin olduğundan gündelik yaşamla bağının kurulması ve yaşamda hangi sorunlara temas ettiğini ve ne gibi çözümler sunduğunu görebilmek zordur. Felsefe her ne kadar bütün bilimlerin anası, bilimlerin kaynağı olarak bilinse de, felsefenin ne işe yaradığı sorusuna "işe yarar" yanıtlar verilememektedir. Felsefe çoğunlukla "düşünme üzerine düşünme" diye tanımlanır ve düşünme üzerine düşünme etkinliği, kaynakların kısıtı olduğu durumlarda fuzuli görülebilir. Bir diğer yaygın görüş de, felsefenin görevinin modern bilimlerin doğmasıyla bilimlere devrolduğu ve felsefenin artk işlevsiz hale geldiğidir (İnam, 2009).

Günümüzde yükseköğrenim alanında yapılan uluslararası düzenlemeler yalnızca felsefenin değil, tüm soyut öğrenim programlarının akademi dışındaki dünyada bir karşılığı olacak şekilde yeniden düzenlenmesini hedeflemektedir (Starkie, 2008 , s. 409-425). Daha açık ifade etmek gerekirse, üniversite lisans programlarının doğrudan bir mesleğe ve o mesleğin gerektirdiği bilgi ve becerilere yönelik olması arzulanmaktadır. Üniversite eğitimine ayrılan kaynak ve zaman düşünüldüğünde, bu eğitimin sonunda somut bir kazanım beklentisi olması kısmen doğaldır. Ancak felsefe eğitiminin tek bir uzmanlık alanına işaret etmesi beklenemez. Felsefe insana doğaya, evrene bir anlam katma derdindedir ve bu çabanın kendisi felsefe öğrencilerinin mezun olduktan sonra yaptıkları işlere de anlam katmalarının önünü açması beklenir.

Ülkemizdeki ve dünyanın başka üniversitelerindeki felsefe bölümlerinin tanıtıcı sayfalarına bakıldığında, felsefe mezunlarının kazanımlarının ve bu kazanımlar sayesinde yapabilecekleri işlerin sıralandığını görürüz. Uluslararası alanda, dünyanın önde gelen üniversitelerinin internet sayfaların felsefe bölümü lisans programından mezun olanların yaptıkları işler ve programın beklenen kazanımları genel olarak tüm sitelerde aşağı yukarı şu şekilde sıralanmaktadır: çeşitli problemler üzerine fikirler oluşturmak, problem ortaya koymak ve bu problemi çözmek, varsayımları ortaya çıkarmak ve alternatifler üretmek, argüman geliştirmek, argümanları mantıksal bir şekilde sıralamak, mantıksal çıkarımlar yapmak, çeşitli eylemlerin karar verme mekanizmalarını incelemek, bir konuyu örneklendirebilmek, verilen örnekleri bir bağlama oturtabilmek, düşünceleri farklı bakış açılarından değerlendirebilmek, sistematik düşünmek ve yazmak vb. (American Philosophical Association, 2008). Felsefe mezunlarının yapttkları işler arasında, akademisyenlik, öğretmenlik, bankacılık, reklamcılık, metin yazarlığı, halka ilişkiler ve insan kaynakları personeli, danışmanlık, araştırmacılık, kütüphanecilik, yazarlık, gazetecilik, pazarlamacılık vb. meslekler yazmaktadır (American Philosophical Association 2002). Kulağa pek inandırıcı gelmese de, Wall Street'in 2010 yılı en iyi para kazanan meslekler arasında felsefecilik, sosyologluğun da birkaç sıra önünde yer alarak 11. sırayı almıştır (Needleman, 2010). 2011 yılından sıralaması düşerek 16. sıraya yerleşmiştir (Light, 2011). Buna rağmen, iktisatçı, kütüphaneci ve diyetisyenin önündedir. (Elbette, bu noktada Kuzey Amerika'da felsefe mezunlarının lisans eğitimlerinin ardından hukuk okuyabileceklerini ve hukuk mezunlarının da kazançlarının toplumun ortalamasına göre yüksek olduğunu hatırlatmakta fayda var.) Ünlü üniversitelerin ve gazetelerin açıklamalarına göre, felsefe mezunları özel işletmelerde daha tercih edilen elemanlar arasındadırlar çünkü felsefe programları tek yönlü insanlar yetiştirmez ve kişinin çok yönlü olması yeni kabiliyetleri daha kolay kazanmasını sağlar (Willamette University, Department of Philosophy, 2018). Yukarıdaki web sayfalarına bakıldığında, yenilikçi, sorgulayıcı ve analitik düşünme yetileri felsefe bölümlerden mezun olanların tercih edilme nedenleri olarak öne çıkmaktadır.

Yalnızca mesleki yaşamda değil, kişilerin birer yurttaş ve evrensel bir insan olarak dünya mirasının taşıyıcısı olan klasik disiplinleri öğrenmesi ve yaşamına uygulaması elzemdir. 2014 yılında Avrupa Birliği Üye ve Aday Ülkeleri arasında yapılan lisansta temel bilimler konusunda düzenlenen konsorsiyumunda, temel bilimlerin ve klasik disiplinlerin önemi

| Kastamonu Eğitim Dergisi, 27(4), 2019| 
vurgulanmıştır (Horizon 2020 ve Avrupa Yükseköğrenim Komisyonu, Quality and relevance in higher education). Üniversite öğreniminin birinci hedefi, öğrencilere meslek kazandırmak değildir ve toplumda da üniversitelerin işlevinin böyle algılanmasının önüne geçilmelidir. Temel bilimler ve felsefe gibi klasik disiplinler öğrencilerin zihinsel kapasitelerini arttırırlar ve bu felsefeyi, zaman zaman adeta moda olan belirli bir iş alanına yönelik bölümlerden daha önemli kılmaktadır. Çotuksöken'in (2016) ifade ettiği gibi, "bir mesleğin dar sınırlarının içine kapatımamış zihinler", problemlere daha geniş, daha bütünsel bakabilirler ve daha analitik çözümler üretebilirler.

Felsefe eğitimi, felsefeyle öğrenim hayatları boyunca az çok karşılaşmış olan bazı kimseler tarafindan filozofların düşüncelerinin ve felsefe tarihinin "ezberlenmesi" olarak bilinmektedir. Böyle anlaşıldığında, felsefenin gündelik yaşamda hangi ihtiyaca denk düştüğü ve ne işe yaradığı anlaşılamamaktadır. Bu nedenle felsefeciler, bu önyargının aksine ezberci bir eğitimden uzak durduklarını ve felsefenin analitik düşünme, sorgulama, kavramsallaştırma, argüman üretme, eleştirme gibi işlevlerini sıklıkla tekrar etmelidirler. Kuçuradi $(2014$, s. 19) felsefenin ne ünlü filozofların düşüncelerinin tekrar edilmesi ne de aklına gelen aykırı düşünceleri söylemek ve demagoji yapmak olmadığında ısrar edilmesi gerektiğini vurgular:

Bir problemi ve arka planı görebilmeyi sağlayan donanımın başlıca kaynaklarından biri, bağlantıları içinde felsefe tarihinin öğretimi-Nietzsche'nin terimleriyle söylersem: antikacı bir anlayışla yapılan felsefe tarihi öğretimi değil, kritik tarih olarak öğretimi-dir.

Felsefe öğretiminden beklenen başka bir şey: ...değerlendirme konusu olan çeşitli nesne türlerinde doğru değerlendirmenin nasıl yapılabileceği konusunda eğitmektir.

...bir başka şey de, kavramlaştırma yollarını öğretmek; dolayısıyla isteyenin istediği tarafa çektiği sözcüklerin kavramlarını açık ve seçik hale getirerek, sömürülmesini olabildiğince önlemesine yardımcı olmaktır. (2014, s. 19)

Kuçuradi'nin sözünü ettiği kazanımları edinmiş felsefecilerin profesyonel yaşamlarında başarılı oldukları ve olabileceklerine ilişkin önemli üniversitelerin felsefe bölümlerinin sayfalarında da bilgiler bulunmaktadır. Örneğin, Kentucky Üniversitesi Felsefe Bölümü "Felsefe beni nereye taşır?" ve North Carolina Üniversitesi Felsefe Bölümü "Neden felsefe lisansı?" başlıklı sayfalarında yayınladıkları kısa makalelerde, felsefenin kazandırdığı yetilerin kullanımına ilişkin deneyimlerini ve gözlemlerini aktarmışlardır (University of Kentucky Department of Philosophy ve University of North Carolina at Chapel Hill Department of Philosophy). Profesyonel yaşamda gerekli olan iletişim becerisi, problem çözme, eleştirel düşünme, yeniliklere açık olma, argüman geliştirme, farklı görüşlere tahammül gösterme, gizli varsayımları ortaya çıkarma, mantıksal çıkarım yapma, problemi ortaya koyabilme, geniş bir perspektiften ve farklı açılardan bakabilme, detaylara dikkat etme, düşünceleri mantksal bir dizge halinde sözlü ve yazılı olarak ifade edebilme gibi yetiler felsefe bölümleri tarafindan öğrencilere kazandırılmaktadır. Görüleceği üzere, felsefe eğitimi, öğrencileri belirli bir sektörde belirli bir konunun uzmanı olarak yetiştirmez. Bu durum başta bir dezavantaj olsa da, felsefeciler felsefenin onlara kazandırdığı yetilerin farkında olduklarında ve çevrelerine bu özelliklere sahip olduklarını kanıtladıklarında başarılı bir kariyere sahip olabilmektedirler. Hatta Anders (2016), felsefe gibi özgür düşünmeye dayalı bir eğitim almış kişilerin daha çok kazandığını ifade etmektedir. Ayrıca Florida Üniversitesi Felsefe Bölümünün hazırladığı derlemeye bakıldığında, felsefe eğitiminin profesyonel yaşamdaki katkılarına ilişin fikir alınabilir. (Florida University, Department of Philosophy).

Buraya kadar, dünyanın önde gelen felsefe bölümlerinin web sayfalarına, önemli gazetelerin makalelerine ve ülkemizin önemli felsefecilerinin röportajlarına bakılarak, felsefe eğitiminin önemi ve felsefe lisans mezunları için tablonun pek karanlık olmadığı görülmüş oldu. Ancak, felsefe lisans programlarının işlevine, mezunlarının durumuna, felsefenin işe yararlılığına ilişkin hiçbir ulusal ve uluslararası akademik çalışmaya rastlanmamıştr. Lise düzeyinde felsefesinin ve çocuklara yönelik eleştirel düşünme eğitiminin önemine ve çıktlarına ilişkin tezler ve akademik çalışmalar yapılmıştr. Ancak, felsefe lisans eğitimine ilişkin tek bir ulusal tez çalışması yapılmıştır. Dr. Osman Kafadar'ın hazırladığı doktora tez çalışması, "Türkiye `de yükseköğretimde felsefe eğitimi: Tarihsel gelişim ve lisans eğitiminin bir incelemesi” başlığını taşımaktadır. Sonradan kitap olarak da yayımlanan bu çalışma, Osmanlı'dan itibaren felsefe eğitiminin gelişimini, felsefeye karşı önyargıları, Cumhuriyet döneminde felsefe bölümlerinin kuruluşunu tarihsel olarak aktarmış ve İstanbul Üniversitesi, Ankara Üniversitesi, Hacettepe Üniversitesi ve Orta Doğu Teknik Üniversitesi felsefe bölümlerinin programlarının karşılaştırmasını sunmuştur (Kafadar, 2000). Bu programların çıktılarına ilişkin herhangi bir veri ortaya koymamış veya yargıda bulunmamıştır. Kısacası, felsefe bölümünün, mezunlarına mezuniyetten sonraki yaşamlarında ne gibi ayrıcalıklar sağladığına ilişkin nitel veya nicel bir çalışma bulunmamaktadır.

Ülkemizde, felsefe bölümlerinin sorunlarına ilişkin 2008, 2009 ve 2011 yıllarında Sakarya Üniversitesi ve 2012'de Mersin Üniversitesi'nde farklı üniversitelerden felsefe bölüm başkanlarının katıldığı felsefe bölümlerinin sorunlarının tartş̧ıldı̆̆ı çalıştaylar yapılmıştır. Bu çalıştaylarda Türkiye'deki felsefe bölümlerinde verilen lisans ve lisansüstü eğitimi- 
nin, felsefe bölümlerinin ve mezunlarının yaşadıkları sorunlar da tartışılmıştır (Karakuş, 2011; Ketenci ve Tosun, 2014). Daha açık olarak, hem Sakarya Üniversitesinde hem de Mersin Üniversitesinde UNESCO'nun çağırısıyla düzenlenen çalıştayda, felsefe lisans ve yüksek lisans programlarının içeriği, müfredat, yeterliliği, kalitesi, Bologna sürecinde akreditasyon sorunları, ilahiyat fakültesinden gelen öğretim üyeleri, açık öğretim fakültelerindeki felsefe programları, mezunların istihdamı ve pedagojik formasyon almaları gibi pek çok sorun masaya yatırılmıştı. Ancak mezunların mevcut durumu nicel olarak çalışılmamıştır. Bu nedenle Kastamonu Üniversitesi Felsefe Bölümü mezunları arasında yapılmış böylesi bir araştırma son derece önemli ve orijinal bir çalışmadır. Ayrıca bu çalışma, sonraki yıllarda başka üniversitelerde yapılacak çalışmalara ilham verecektir.

\section{Araştırmanın Amacı ve Soruları}

Bu çalışma Kastamonu Üniversitesi Felsefe Bölümü’nden mezun olmuş olan öğrencilerin bu programda almış oldukları öğrenimin onların kişisel ve mesleki yaşamlarına katkısını anlamayı amaçlamaktadır. Felsefe bölümü mezunlarının sistematik bir takibi yapılmadığından, felsefe bölümü mezunları ne iş yapar sorusuna yüzeysel cevaplar verilebilmektedir. Özellikle, mezun olduktan sonra yapabilecekleri işlerin belirgin olmaması, öğrencilerin çoğunun karamsarlığına neden olmaktadır. Öğrenciler, felsefe bölümündeki hocalarına sordukları sorulardan, toplumdaki önyargıları silebilecek yanıtlar beklemektedirler. Hocalarından bu konuda da net yanıtlar duymayı ve bir takım iş alanlarına henüz lisansı bitirmeden yönlendirilmeyi de talep etmektedirler. Bu araştırma, öğrencilerin bu tür sorularına ve sorunlarına yanıt olabilecek verileri doğrudan mezunların kendi ağızlarından sunmayı hedeflemektedir.

Kastamonu Üniversitesi Felsefe Bölümü mezunlarının bir kısmıyla yüz yüze ve çoğuyla telefonla birebir görüşmeler yapılmıştır. Mezunlara, hem kişisel hem de profesyonel yaşamlarında, felsefe okumuş olmanın ayrıcalıklarını deneyimleyip deneyimlemedikleri, şu an veya geçmişte uğraştkları işlerde, felsefenin onlara ve işlerine getirileri olup olmadığı sorulmuştur. Felsefenin temel işlevlerinden olan, gözlemleme, görme, algılama, anlama, değerlendirme, problem çözebilme, yeniliklere açık olma, sorgulama, analitik düşünme, muhakeme etme ve alınan kararları gerekçelendirme gibi nitelikleri kazanıp kazanmadıkları anlaşılmaya çalışılmışır. Felsefe lisans programında kazanılması beklenen bu yetileri kişisel ve profesyonel yaşamlarında tatbik edip etmedikleri irdelenmiştir. Felsefe bölümü mezunlarına yönelik böyle bir çalışmaya ulusal literatürde rastlanmamıştır. Dolayısıyla, yapılan bu araştırma literatüre önemli bir katkı niteliği taşımaktadır. Çalışmanın önemli bir diğer amacı da, lisans düzeyinde felsefe okumanın sanıldığı gibi olumsuz katkıları olmadığını, aksine olumlu kazanımlara yol açtığını ortaya koymaktır. Bu beklenti verilerle doğrulandığında, felsefe lisans eğitiminin önemini daha somut bir şekilde duyurulabilecektir. Literatürde böyle bir çalışma yer almadığı için, araştırmanın sonuçları akademik bir değer taşımaktadır. Ayrıca bu görüşmelerde, felsefe öğrencilerinin toplumumuzdaki önyargılardan ne derece etkilendikleri, felsefe bölümünün özel ve profesyonel yaşamlarına katkıları, mezun olduktan sonra iş bulmakta bölümün avantajları ve dezavantajları, halen felsefeyle uğraşıp uğraşmadıkları sorulmuştur.

Bu çalışmanın önemli bir katkısı da, Kastamonu Üniversitesi Felsefe Bölümü programının başarısının bir ölçüde ölçülmesi olacaktır. Programın eksiklikleri ortaya konulup, mevcut program öğrencilerin mezun olduktan sonraki yaşamlarına daha doğrudan katkı sağlayacak şekilde düzenlenebilir. Bölümü tercih etmeyi düşünen öğrenciler, halihazırda felsefe okuyan öğrenciler ve yeni mezunlar "meslektaşlarının" bölümde okurken kendilerini nasıl geliştirdiklerini, bölümün onlara sağladığı katkılarını ve profesyonel olarak felsefe bölümü mezunu olmanın getirilerini görmelidirler. Bu sayede öğrenciler kendilerini mezun olmadan önce istedikleri işlere daha güvenle kanalize edebileceklerdir.

Bu amaçlar doğrultusunda Kastamonu Üniversitesi Felsefe Bölümü’nde okumuş ve mezun olmuş kişilere 25 adet açık uçlu soru sorulmuştur:

1. Felsefe Bölümüne isteyerek mi geldiniz?

2. Bu bölüme gelme nedenlerinizi (isteyerek geldiyseniz de gelmediyseniz de) açıklar mısınız?

3. Kastamonu Üniversitesi Felsefe Bölümü tercihleriniz arasında kaçıncıydı?

4. Felsefe Bölümüne gelmeden önce, felsefenin ne anlama geldiğini biliyor muydunuz?

5. Kastamonu Üniversitesi Felsefe Bölümünde geçirdiğiniz yıllardan genel olarak memnun musunuz?

6. Bölümden memnuniyetinizin ya da memnuniyetsizliğinizin nedenlerini açıklar mısınız?

7. Şu anda ne iş yapıyorsunuz? Yüksek Lisans/Doktora yapıyor musunuz?

8. Bu iş, mezun olduktan sonraki kaçıncı işiniz? Varsa daha öncekiler nelerdi?

9. Mezun olduğunuzda iş bulmakta zorlandınız mı?

10. İş ararken veya iş için bir sınava hazırlanırken, felsefe bölümünden mezun olmanın avantajları ve dezavantajları oldu mu? 
11. Felsefe okumanın, şu an çalıştı̆ııız veya geçmişte çalıştğınız işlere olumu ya da olumsuz bir katkısı oldu mu? Bu katkıların neler olduğunu açıklar mısınız?

12. Felsefe okumuş olmak hayatınızı veya kişiliğinizi değiştirdi mi?

13. Değiştirdiyse de değiştirmediyse de nedenlerini açıklar mısınız?

14. Felsefe eğitiminiz süresince yaşamınızı ve sizi etkileyen önemli felsefeciler veya kuramlarla karşılaştınız mı? Karşılaştiysanız kimler ve neler olduğunu açıklar mısınız?

15. Bölümün ve programın eksikleri olduğunu düşünüyor musunuz? Eksikler olduğunu düşünüyorsanız, bunlar sizce nasıl giderilebilir?

16. Ders içeriklerini tatmin edici buldunuz mu?

17. Seçmeli derslerin yeterli olduğunu düşündünüz mü? Başka seçmeli dersler almak ister miydiniz? İsterdiyseniz, bunlar neler olurdu?

18. Hangi dersler/konular aklınızda, hayatınıza yön verdi? Aklınızda kalanlar nelerdir?

19. Üniversiteye gidecek olan yakınlarınıza/öğrencilerinize bu bölümü tavsiye eder misiniz?

20. Toplumumuzda felsefeye ilişkin önyargılarla karşılaştınız mı?

21. Bu önyargıların doğru olduğunu düşünüyor musunuz?

22. Toplumdaki önyargılardan ne derece etkilendiniz?

23. Bu önyargılara ne gibi tepkiler veriyorsunuz?

24. Bölümden mezun olduktan sonra felsefeyle uğraşmaya devam ediyor musunuz?

25. Şu anda felsefe değil de başka bir bölüm okumuş olmayı diler miydiniz?

\section{Yöntem}

Bu çalışma, amaçsal açıdan, tanımlayıcı/betimleyici nitelikte bir araştırma olup kapsamlı birkaç amaç hedeflenerek planlanmıştır. Öncelikle bu çalışma Kastamonu Üniversitesi Felsefe Bölümü’nden mezun olmuş olan öğrencilerin bu programda almış oldukları öğrenimin onların kişisel ve mesleki yaşamlarına katkısını ölçmeyi amaçlamaktadır. Dolayısıyla, ilk elden 2013 yılından bu yana bu programdan mezun olanların (2016 mezunları hariç) listesi çıkartılmıştı. Ardından, mezun olmuş öğrencilerle iletişime geçilmiş ve araştırmadan bahsedilmiştir. Geliştirilen görüşme formundaki sorular, görüşülecek öğrencilere tek tek okunmuştur. Derinlemesine ve birebir yapılan görüşmelerde nitel veriler elde edilmiştir. Nitel verilerin analizi, nitel veri analizi tekniklerinden tümevarım analizi ve betimsel analiziyle yapılmıştır. Tümevarım analizi, önceden belirgin olmayan temaları ve boyutları ortaya çıkarmaya, kavramlara ve ilişkilere ulaşmaya olanak sağlaması ile verilerin derinlemesine çözümlemesini gerektiren bir analiz yöntemidir. Tümevarım analizi için öncelikle araştırma soru ve sorunlarına dayalı olarak gruplandıılan veriler okunup, verilerin doğası ve genel görünümü ortaya konulmuştur. Son olarak, elde edilen bulgular, araştırma sorularını yanıtlamadaki önem derecelerine göre ilgili metinlerle zenginleştirilerek yorumlanarak doğrudan alıntılarla bulgular desteklenmiştir. Betimsel analizse, araştırmanın kavramsal yapısının önceden açık bir biçimde belirlendiği araştırmalarda kullanılmakta olan bir analiz tekniğidir. Betimsel analizde temel amaç, nitel verilerin nicelleştirilerek frekanslarla betimsel olanak analiz edilmesi ile elde edilen bulguların düzenlenmiş ve yorumlanmış bir şekilde okuyucuya aktarılmasını sağlamaktadır (Balcı, 2001).

\section{Çalışma Grubu:}

Çalışma grubu evrenin tamamı olarak belirlenmiştir. illk kez ek yerleştirmeyle 2009 yılında öğrenci alan Kastamonu Üniversitesi Felsefe Bölümü, 2013-2016 yılları arasında toplam dört yıl mezun vermiştir. Ancak bu araştırmaya 2016 yılı mezunları dahil edilmemiştir. Araştırma başladığında, 2016 yılı mezunlarının mezun olmalarının ardından henüz birkaç ay geçtiği için, iş bulmamış oldukları ve mezuniyetlerinin ardından nesnel bir değerlendirme yapamayacakları varsayılmıştır. 2013 yılında 26, 2014'te 46, 2015 yılında 38 öğrenci mezun olmuştur. 2013 mezunlarından 19, 2014 mezunlarından 34, 2015 mezunlarından 24 kişiyle görüşülmüştür. Toplamda 77 mezunla, yani mezunların yüzde 70'iyle görüşülmüştür. 2013 yılı mezunlarından görüşülenlerin 3'ü erkek, 16'sı kadındır; 2014 yılı mezunlarından görüşülenlerin 3'ü erkek, 31'i kadındır; 2015 yılı mezunlarından görüşülenlerin 2'si erkek, 22'si kadındır.

\section{Veri toplama aracı ve araştırma süreci:}

Araştırmada araştırmacı tarafindan geliştirilen açık uçlu 25 sorudan oluşan nitel görüşme formu kullanılmıştr. Bu form, felsefe bölümüne kendi istekleriyle gelip gelmedikleri, bölümde geçirdikleri yıllardan memnun olup olmadıkla$\mathrm{rı}$, mezun olduktan sonra iş bulma sürecinde zorluk yaşayıp yaşamadıkları, felsefe okumayı çevrelerine tavsiye edip etmeyecekleri gibi sorular içermektedir. Bu sorulara verdikleri yanıtlarla, mezuniyetlerinin ardından hem felsefeye ve bölüme ilişkin düşünceleri, hem de felsefe okumuş olanların iş bulma kolaylığı/zorluğu üzerine tecrübeleri öğrenilmiştir. 
Öğrenci işlerinden alınan listedeki çoğu mezunun iletişim bilgileri sosyal medya ve arkadaşları aracılığıyla bulunmuştur. Bir kısmına hiçbir yolla ulaşılamamıştr. Yine sosyal medya aracılığıyla, mezun olmuş öğrencilerle iletişime geçilmiş ve araştırmadan, amacından ve öneminden haberdar olmaları sağlanmıştır. Görüşmeyi kabul eden öğrencilerin aydınlatılmış onamları alınmış ve telefon numaraları istenmiştir. Görüşmeler, proje yürütücüsü Kastamonu Üniversitesi Felsefe Bölümünün bir öğretim üyesi olduğundan, öğrencilerin kendilerini rahat ve açık ifade edememe riskini bertaraf etmek için yürütücü tarafindan yapılmamıştır. Görüşmeler bir araştırma şirketi tarafindan yapılmıştır. Görüşmeye başlanmadan önce, verdikleri yanıtların, onların rızalarıyla kaydedileceği söylenmiştir. Görüşmeyi kabul eden bütün mezunlar ses kaydı alınmasını da kabul etmişlerdir.

\section{Verilerin çözümlenmesi:}

Verilerin çözümlenmesi amacıyla ilk önce ses kayıtları çözümlenmesi yapılmıştır. Mezunların bu sorulara verdikleri yanıtlar, hem ses kayıtları hem de Microsoft Word dosyasına yazılı bir şekilde araştırma şirketinden elde edilmiştir. Sonra, yanıtlar Microsoft Excel programına girilmiş ve nicel bir analiz için sınıflandırılmıştır. Sorular baz alınarak yapılan bu nicel sınıflandırmayla birlikte mezunların cevapları da tasnif edilmiştir. Daha sonra, bu Excel tablolarına bakılarak, nitel ve betimsel bulgulara ulaşılmıştr. Bu bulgular, ülkemizin önde gelen felsefe profesörlerinin yukarıda bahsi geçen çalıştaylarda sundukları konuyla ilgili bildirileriyle birlikte tartışılmıştır.

\section{Bulgular}

Kastamonu Üniversitesi Felsefe Bölümü mezunlarına yönelik yapılan çalışma, toplamda yirmi beş soruya verilen açık uçlu yanıtların analizinden oluşmaktadır. Lisans programı 2013 yılından bu yana, dört yıldır mezun vermektedir. 2016 yılında mezun olan son grup, henüz mezuniyetlerinin ardından pek fazla süre geçmediğinden araştırmaya dahil edilmemiştir. 2013 yılında 26, 2014'te 46, 2015 yılında 38 öğrenci mezun olmuştur. 2013 mezunlarından 19, 2014 mezunlarından 34, 2015 mezunlarından 24 kişiyle görüşülmüştür.

Tablo 1. Mezunlardan görüşülebilenlerin ve bölüme isteyerek gelenlerin sayısı ve oranları.

\begin{tabular}{lccccc}
\hline $\begin{array}{l}\text { Mezuniyet } \\
\text { yılları }\end{array}$ & $\begin{array}{c}\text { Mezun olan öğrenci } \\
\text { sayıları }\end{array}$ & $\begin{array}{c}\text { Görüşülenlerin } \\
\text { sayısı }\end{array}$ & $\%$ & $\begin{array}{c}\text { Felsefe Bölümüne isteyerek geldiğini söyle- } \\
\text { yenlerin sayısı }\end{array}$ & \% \\
\hline 2013 & 26 & 19 & 73 & 11 & 57,8 \\
2014 & 46 & 34 & 73,9 & 23 & 67,6 \\
2015 & 38 & 24 & 63 & 17 & 70,8 \\
\hline Toplam & 110 & 77 & 70 & 51 & 66 \\
\hline
\end{tabular}

Araştırma, mezunların Kastamonu Üniversitesi Felsefe Bölümüne isteyerek gelip gelmedikleri sorusuyla başlamaktadır. Araştırmaya katılan mezunlardan toplamda 51'i isteyerek geldiğini belirtmişlerdir. Yıllara göre bir değerlendirme yapılırsa, Tablo 1'de de görüldüğü gibi, 2013 mezunlarından görüşülen 19 kişiden 11'i, 2013 mezunlarından görüşülen 34 kişiden 23'ü, 2015 mezunlarından görüşülen 24 kişiden 17'si isteyerek geldiğini söylemiştir. Peşi sıra gelen ikinci soru, bu bölüme gelme nedenlerini sormaktadır. Bu soruya yanıt veren 77 kişiden 23 'ü felsefe öğretmenini ve dersi sevdiğini, ilgi ve merak duyduğunu, isteyerek geldiğini söylemiş; 17'si de felsefe veya rehber öğretmeni olmak için tercih ettiğini belirtmiş; 6 'sı da felsefeyle ilgilenenlerin geniş bilgi yelpazesinden etkilendiği ve daha geniş düşünmek hayata çok yönlü bakabilmek için tercih ettiğini söylemiştir. Geriye kalanlar ise; dershane hocalarının yönlendirmesi, iyi bir gelecek için, memur olmak ve rehabilitasyon merkezlerinde çalışmak için tercih etmiştir. Ayrıca istemeyerek, bilinçsizce, şans eseri, tercih yanlışlığı ve sıralamasından gelenler 9 kişidir. Bunun yanında ek tercihin açılması, aile baskısı, puanın ancak buraya yetmesi, açıkta kalmama ve lisans mezunu olabilmek için tercih edenlerin sayısı 16'dır. Burada 2013 yıIında Kastamonu Üniversitesi Felsefe Bölümünün ilk kez öğrenci almaya başladığını ve ek kontenjanla öğrenci aldığını belirtmek gerekir.

Üçüncü soru, Kastamonu Üniversitesi Felsefe Bölümünü kaçıncı sırada tercih ettikleriydi. Kastamonu Üniversitesi bünyesinde Felsefe Bölümü 2009 yılında ek yerleştirmeyle öğrenci almıştr. 2013 yılında bölümün ilk mezunları olarak mezun olan bu öğrenciler ek yerleştirmeyle bu bölümü tercih ederek gelmişlerdir. Bu soruya verilen yanıtlara bakıldığında, ilk sıralarda tercih edenler olduğu gibi, son sıralarda tercih edenlerin olduğu da görülmektedir. 2014 mezunu olan 34 kişiden 9 kişinin tercih sıralaması ilk on tercihin içindedir. 23 kişinin ise tercihleri onuncu sıradan sonradır. Kalan iki kişiden biri yatay geçiş, diğeri ise ek yerleştirme ile gelmiştir. 2015 mezunu olan 24 kişiden 18'inin tercih sıralaması ilk on tercihin içinde iken, kalan 6 kişinin ise tercihleri onuncu sıradan sonradır.

Dördüncü soru olan, "felsefe bölümüne gelmeden önce felsefenin ne anlama geldiğini biliyor muydunuz?” soru- 
suna, 77 kişiden 57'si felsefenin ne anlama geldiğini bildiğini, 14'ü felsefenin anlamını bilmediğini, kalan 7'si ise biraz bildiklerini belirtmiştir.

Felsefe bölümüne neden geldiklerini anlamaya yönelik bu soruların ardından, Kastamonu Üniversitesi Felsefe Bölümünde geçirdikleri yıllara ve aldıkları eğitime ilişkin sorulara geçilmiştir. Memnun olup olmadıklarına ilişkin 5. soruya, 77 kişiden yalnızca 4'ü felsefe bölümünde geçirdiği yıllardan memnun olmadığını, geri kalan diğer 73 kişi felsefe bölümünde geçirdiği yıllardan memnun olduğunu söyledi. Bölümde geçirdikleri yıllardan memnun olduklarını söyleyenler bile, peşi sıra gelen 6 . soruda çeşitli sorunlar dile getirdiler. Memnuniyetsizliklerinin nedenleri genel olarak şöyle sıralanabilir: bina sıkıntısı, iş bulma kaygısı, bölümde az sayıda öğretim üyesi bulunması, dersleri destekleyici kaynaklara erişimin yetersiz olması. Bina sıkıntısından özellikle 2013 yılı mezunlarının mustarip olduğu görülmüştür çünkü 2009-2010 yılları arasında Felsefe Bölümünün bulunduğu Fen Edebiyat Fakültesi yerleşke olarak bir lisenin binasını kullanmaktaydı. Liseden çıkıp hevesle üniversiteye gelen öğrenciler, tekrar bir lise binasında öğrenim görmekten dolayı hayal kırıklığına uğramışlardır. Memnuniyetlerinin nedenleriyse, genel olarak şöyle sıralanabilir: hocaların samimi olması, öğrencilere yakın davranması ve bölüm derslerini sevdirmeleri, felsefe bölümünün öğrencilere farklı bakış açısı kazandırması, bölümün öğrencilerin kendilerine duydukları özgüveni arttrrması, kendilerini sözel ve yazılı olarak başkalarına göre daha iyi ifade edebilmeleri. Mezunların aktardıkları sıkıntılara rağmen, bölümde geçirdikleri yıllardan memnuniyet duymalarında, felsefenin kendisinin payı yadsınamaz.

Tablo 2. Mezuniyet yıllarına göre iş durumu*.

\begin{tabular}{lcccccc}
\hline $\begin{array}{l}\text { Mezuniyet } \\
\text { yılları }\end{array}$ & $\begin{array}{c}\text { Halihazırda bir } \\
\text { işte çalışanlar }\end{array}$ & İşsiz olanlar & $\begin{array}{c}\text { Çalışanların } \\
\text { yüzdesi }\end{array}$ & $\begin{array}{c}\text { Yüksek Lisans ya- } \\
\text { panlar }\end{array}$ & $\begin{array}{c}\text { Özel sektörde iş } \\
\text { aramayanlar }\end{array}$ & $\begin{array}{c}\text { İşizlerin } \\
\text { yüzdesi }\end{array}$ \\
\hline 2013 & 11 & 8 & 57,8 & 2 & 7 & 5,2 \\
2014 & 21 & 13 & 61,7 & 2 & 10 & 8,8 \\
2015 & 11 & 13 & 45,8 & 2 & 10 & 12,5 \\
\hline Toplam & 43 & 34 & 55,8 & 6 & 27 & 9,09 \\
\hline
\end{tabular}

${ }^{*}$ Mezuniyet sonrası çalışanların, işsizlerin, yüksek lisans eğitimine devam edenlerin, iş aramayanların sayıları verilmiştir. İşsizlerin yüzdesi hesaplanırken, özel sektörde iş aramayanlar işsizlere dahil edilmemiştir.

7-11. sorular mezunların çalıştıkları işlere, iş bulma konusunda bölümlerinin olumlu ya da olumsuz etkilerini görüp görmediklerini anlamaya yönelik sorulardan oluşmaktadır. 2013 yılı mezunlarıyla yapılan görüşmelerde; 19 mezunun $11^{\prime} i$ çalıştı̆̆ını, 9'u işsiz olduğunu söylemiştir. Çalışanlardan 2'si ücretli öğretmen, $1^{\prime} i$ araştırma görevlisi, $1^{\prime} i$ rehber öğretmen, $1^{\prime} i$ zabıt katibi, 1'i satş danışmanı, 2'i özel eğitim öğretmeni olarak, $1^{\prime} i$ rehabilitasyon merkezinde, $1^{\prime} i$ PTT'de çalışmaktadır. İşsiz olan mezunlardan 2'si yüksek lisans eğitimine devam etmektedir, 1'i askerde olduğu için ücretli bir işte çalışamamaktadır, 5 mezun da devlet memuru olmak istediklerini, bu nedenle özel sektörde iş aramadıklarını belirtmişlerdir. 2014 yılı mezunlarından 34 mezunun 21'i çalışmakta, 13'ü işsizdir. Çalışanlardan 3’ü ücretli öğretmenlik, 3'ü hem felsefe hem rehber öğretmenliği yaptığını, 3'ü rehber öğretmen, 2'si muhasebeci olarak çalıştğını, 2'si özel bir kurumda, 2'si rehabilitasyon merkezinde, 1'i kendi iş yerinde, $1^{\prime} i$ çağrı merkezinde, 1'i psikolog, 1'i avukat katibi, $1^{\prime} i$ komiser yardımcısı, 1'i de özel bir yurtta müdür yardımcısı olarak çalıştğı̆nı belirtmiştir. İşsiz olan mezunlardan 2'si yüksek lisans yapmaktadır. İşsiz olanlardan 10'u özel sektörde iş aramamaktadır. Bu mezunlardan birisi şunları ifade etmiştir: "Şu anda çalışmıyorum. YDS için yabancı dil kursuna gidiyorum. Hiç çalışmadım. Zaten iş bulmak da istemedim. Yapmak istesem çok iş var zaten. Arkadaşlarım özel kurumlarda felsefe öğretmenliği veya ücretli öğretmenlik yapıyorlar. Ama ben öyle bir çaba içerisine girmedim." 2015 yılı mezunlarıyla yapılan görüşmelerde, 24 mezunun 11'inin çalıştğı, 13'ünün işsiz olduğu görülmektedir. Çalışanlardan 5'i rehber öğretmeni, $1^{\prime}$ i felsefe grubu öğretmeni, $1^{\prime} i$ felsefe ve rehber öğretmeni, 1'i ücretli öğretmen, 1'i psikolog olarak, 1'i de etüt merkezinde çalışmaktadır. Mezunlardan birisi roman yazmıștır, halen romanın tanıtımıyla ilgilenmektedir ve ikinci romanı üzerinde çalışmaktadır. Bunun yanında çaIışan mezunlardan biri, işsiz mezunlardan da biri olmak üzere toplam 2 mezun yüksek lisans eğitimi görmektedir. 2015 yılı mezunlarından 10'u ciddi ciddi iş aramadıklarını ifade etmişlerdir. Bu noktada, mezunların önemli bir kısmının okul biter bitmez evlendiğinin gözlemlendiğini belirtmek gerekir. Evliliğe ilişkin bir soru sorulmadığı için bu hususta bir oran verilememektedir. Kadın mezunların bir kısmı "ev hanımı" olarak yaşamlarını devam ettirmekte ve özel sektörde ücretli bir iş aramamaktadır. "Devlette çalışmayı" bekleyenlerin bir kısmını da bu grup oluşturmaktadır.

2013 yılı toplam 19 mezunun, 6'sı daha önce hiç çalışmadığını, 5'i ilk işi olduğunu, 8'i de ikinci işi olduğunu söylemiştir. íkinci işi olan 8 mezundan daha önce 3'ü ücretli öğretmen, $1^{\prime} i$ araştırma görevlisi, $1^{\prime} i$ felsefe ve rehber öğretmeni, $1^{\prime} i$ anaokulu öğretmeni, $1^{\prime} i$ de gönüllü öğretmen olarak çalışmıştr. Ayrıca şu an işsiz olup daha önce ücretli öğretmenlik, felsefe ve rehber öğretmeni olarak çalıştı̆̆ını belirten mezunlarda olmuştur. 2014 yılı 34 mezunun, 8'i hiç çalışmadığını, 19'u ilk işi olduğunu, 4'ü ikinci işi olduğunu, 2'si üçüncü işi olduğunu ve 1'i de dördüncü işi olduğunu söylemiştir. İkinci 
işi olan 4 mezundan daha önce, 1'i garson, 1'i dershanede öğretmenlik, 2'si de ücretli öğretmenlik yaptı̆̆ını söylemiştir. Üçüncü ve dördüncü işi olan mezunlar daha önce felsefe öğretmenliği, rehber öğretmenliği yapmış; dershane ve özel okullarda çalışmışlardır. Şu an işsiz olup da daha önce dershanede öğretmenlik, ücretli öğretmenlik, sınıf öğretmeni ve felsefe öğretmeni olarak çalıştıklarını söyleyen mezunlar da vardır. 2015 yılı 24 mezunun, 7'si daha önce hiç çalışmadığını, 12'si ilk işi olduğunu, 4'ü ikinci işi olduğunu, 1'i de dördüncü işi olduğunu söylemiştir. íkinci işi olan 4 mezundan 2'si ücretli öğretmenlik, $1^{\prime} i$ felsefe ve rehber öğretmenliği yaptığını, $1^{\prime} i$ de rehabilitasyon merkezinde çalıştığını belirtmiştir. Dördüncü işi olduğunu söyleyen mezun ise markette, kırtasiyede ve kütüphanede çalıştğını söylemiştir. Şu an işsiz olup da daha önce sınıf öğretmenliği, ücretli öğretmenlik, muhasebecilik yapan, özel ders veren, kolejde çalışan ve roman yazan mezunlar olmuştur.

Tablo 3. Mezuniyet sonrasında iş bulma zorluğu

\begin{tabular}{lccc}
\hline Mezuniyet yılları & Zorlandım & Zorlanmadım & İ̧̧ aramadım \\
\hline 2013 & 15 & 3 & 1 \\
2014 & 23 & 7 & 4 \\
2015 & 15 & 7 & 4 \\
\hline Toplam & 53 & 17 & 9 \\
\hline
\end{tabular}

“Mezun olduğunuzda iş bulmakta zorlandınız mı?” sorusuna; 2013 mezunlarından 15'i zorlandığını, 3'ü zorlanmadığını, 1'i de iş aramadığını; 2014 mezunlarından bu soruya 23'ü zorlandığını, 7'si zorlanmadığını, 4'ü iş aramadığını; 2015 mezunlarından 15'i zorlandığını, 7'si zorlanmadığıı, 2'si iş aramadığını belirtmiştir. Ardından gelen soru iş ararken felsefe mezunu olmanın avantajlarını ya da dezavantajlarını yaşayıp yaşamadıkları üzerinedir. 2013 yılındaki 19 mezundan 11'i dezavantajı olduğunu, 3'ü avantajı olduğunu, 4'ü ikisinin de olmadığını ve $1^{\prime}$ i de hem avantajının hem dezavantajının olduğunu söylemiştir. 2014 yılı 34 mezundan 16'sı dezavantajı olduğunu, 8'i avantajı olduğunu, 6'sı hem avantajının hem dezavantajının olduğunu, 2'si etkisi olmadığını söylemiş, kalan 2 kişi de yanıt vermemiştir. 2015 yılındaki 24 mezundan 9'u dezavantajı olduğunu, 6'sı avantajı olduğunu, 7'si hem avantajının hem dezavantajının olduğunu ve 2'si de etkisi olmadığını söylemiştir. Bu soruyla ilgili olarak, peşi sıra, "Felsefe okumanın şu an çalıştığınız veya geçmişte çalıştğınız işlere olumlu ya da olumsuz bir katkısı oldu mu? Bu katkıların neler olduğunu açıklar mısınız?" sorusu sorulmuştur. Mezunlar bu soruda çoğunlukla felsefe okumuş olmanın çalıştıkları işlere olumlu katkıları olduğunu söylemişlerdir. Felsefe eğitimi sayesinde, çalıştıları işlerde fark yaratan elemanlar olduklarını ve kazandıkları şu yetilerin işlerine olumlu katkıları olduğunu belirtmişlerdir: farklı düşüncelere saygı duyma, özgün düşünebilme, insanlarla rahat ve etkili iletişim kurabilme, insanları daha iyi anlayıp dinleyebilme, sözel ve yazılı olarak kendisini daha rahat ifade edebilme, olaylara farklı açılardan bakabilme, sorunlar karşısında çok yönlü düşünebilme, sorgulama ve eleştirel düşünme. Ancak aynı zamanda felsefe mezunu olmuş olmanın olumsuz yönleri olduğunu da eklemişlerdir. Bu olumsuzluklar genellikle, toplumumuzda felsefeye karşı beslenen önyargılarla ilişkilidir. En başta, iş ararken karşılaştikları zorluklar, kazandıkları "felsefeci" unvanının doğrudan bir iş alanına işaret etmemesi, görüşme boyunca şikayet ettikleri temel sorundur.

12. soru olan "Felsefe okumuş olmak hayatınızı ve kişiliğinizi değiştirdi mi?" sorusuna, toplamda 70 mezun "değiştirdi" yanıtını vermiştir. Daha sonra "bu değişiklerin olması ve olmamasının nedenleri" sorulduğunda; alınan yanıtlara göre, felsefe eğitiminin hayatlarına ve kişiliklerine kattğı değişimler "hayata ve kişilere farklı açılarda bakabilme, dar kalıplardan kurtulma, objektif olabilme, önyargıları ortadan kaldırma, kişilik olarak aktifleşme, duydukları herhangi bir şeyi körü körüne kabullenmeme, araştırma, sorgulama, farklı cinsiyet ve düşüncelere saygı gösterme, hoşgörülü olma, kendini iyi ifade edebilme, düşüncelerini farklı pencereler sunabilme, mantkklı ve sakin düşünebilme, düşünceler üzerinde yoğunlaşabilme, farklı argümanlar kullanarak iletişim kurma, eleştirel gözle bakabilme, evreni sorgulama, özgürlüğe saygı duyma" yönünde olmuştur. Mezun olan öğrencilerden birisinin kullandığı şu ifade dikkat çekicidir: "Aldığım dersler sayesinde ataerkil bir toplumda yaşadığımı fark ettim. İnsanlara yapılan eşcinsellere yapılan ayrımı fark ettim. Bu ayrımı artkk ben yapmıyorum." Aldıkları dersler, derslerde gördükleri farklı düşünceler, filozofların fikirleri, bölümdeki öğretim elemanlarının öğrencilere yaklaşımları, kişilikleri, bakış açıları öğrencilerdeki bu değişim üzerinde etkilidir. Bazı mezunlar, "derslerin ve hocaların hayat sorgulatmalarının zamanla öğrencilerin kendilerini de sorgulamalarına neden olduğunu ve yine zamanla kendi değer yargıları, davranış ve tutumlarını değiştirdiğini" ifade etmişlerdir. Felsefenin hayatlarını değiştirmediğini söyleyenler, felsefeyi herhangi bir lisans programı olarak görmüş ve "öğrenci mantığıla" yalnızca derslerden geçmeye ve diploma almaya odaklanmış olduklarını, belirtmişlerdir.

14. soru olan, "Felsefeye eğitiminiz süresince yaşamınızı ve sizi etkileyen önemli felsefeciler veya kuramlarla karşılaştınız mı? Karşılaştıysanız kimler ve neler olduğunu açıklar mısınız?" sorusuna çok farklı yanıtlar verilmiştir. 77 mezundan toplamda 21'i karşılaşmadığını veya hatırlamadığını söylemiştir. Diğerleri, Heraklitos, Sokrates, Platon, Aristoteles, 
Gazali, Farabi, İbn Haldun, İbn Sina, İbn Rüşt, Thomas More, Descartes, Spinoza, Locke, Kant, Schopenhauer, Hegel, Schiller, Marx, Nietzsche, Freud, Russell, Sartre, Foucault, Rawls, Kuçuradi, gibi akıllarına gelen filozofları sıralamışlardır. Çoğu doğrudan felsefe öğretmenliği yapmadığı için bu soruya bir süre düşünerek, hatrlamaya çalışarak cevap vermiştir. Bu soruya verilen şu tür açıklayıcı yanıtların dikkate alınması daha uygun olacaktır: "Sokrates'in savunması, Sokrates, Platon ve Aristoteles'in erdem anlayışları, Platon'un devlet anlayışı, Aristoteles'in fizik-eylem görüşü, Aristoteles'in insan doğası, Aristoteles'in ahlakı ve siyaseti, İslam filozoflarının din anlayışları, Farabi'nin siyaset felsefesi, More'un Ütopya'sı, Descartes'ın 'düşünüyorum öyleyse varım' önermesi, Descartes'ın Tanrı kanıtlaması, Kant'ın ahlakı, Hegel'in sentez kuramı, Hegel'in Tin kavramı, Hegel'in köle-efendi diyalektiği, Marx'ın siyaset felsefesi, Rawls'un siyaset felsefesi, Nietzsche'nin köle ahlakı, faydacılık, Russell'ın felsefi düşünceleri, Sartre'ın özgürlük düşüncesi, zihin felsefesi dersinde zihnin beynin bir fonksiyonu olduğunu kanıtlamaya yönelik verilen örnekler, insan hakları, toplumsal cinsiyete ilişkin kavramlar..."

Bu kısımdan sonraki dört soru Kastamonu Üniversitesi felsefe lisans programını nasıl değerlendirdiklerine ilişkindir. 15. Soru olan "Bölümün ve programın eksikleri olduğunu düşünüyor musunuz? Eksikler olduğunu düşünüyorsanız, bunlar sizce nasıl giderilebilir?" sorusuna, 20 kişi ise bölümün ve programın eksikliği olduğunu düşünmediklerini söylemiştirler. Geri kalan 57 kişi bölümün ve programın eksiklerini şöyle sıralamışlardır: bazı derslerde ezbere dayalı eğitim verilmesi, derslerde ve ödevlerde kullanılacak kaynaklara ulaşamama, yeterli sayıda öğretim üyesi olmaması, seminer ve kongrelerin az olması. Ders içerikleriyle ilgili olarak; 77 kişiden $69^{\prime}$ u ders içeriklerinin tatmin edici olduğunu düşünüyor. Geri kalan 8 kişi ders içeriklerini tatmin edici bulmadığını söylüyorlar. Ders içeriklerini tatmin edici bulmayanlar şu sorunları dile getirdiler: "öğretim üyelerinin kendi uzmanlık alanlarının dışındaki derslere girmesi, ders içeriklerinin kendilerini mezun olduktan sonra yapttkları işlere hazırlamaması." Seçmeli derslerle ilgili olarak; 77 kişiden 52'si seçmeli derslerin yeterli olduğunu düşünüyor. Geri kalan 25 kişi seçmeli derslerin yetersiz olduğunu söylüyor. Yunanca, Fransızca, İspanyolca gibi dil dersleri, resim, matematik felsefesi, sinema felsefesi, diksiyon dersi, daha fazla sosyoloji ve psikoloji dersleri almak istediklerini belirtmişlerdir. Mezunların bir kısmı rehberlik ve danışmanlık alanında çalıştığı için, bu alana katkı sağlayabileceklerini düşündüklerinden, daha fazla psikoloji dersi almak istediklerini eklemişlerdir. Hayatlarına yön veren derslerin neler olduğu sorusuna da, birbirinden farklı pek çok yanıt verilmiştir, bölümde açılan neredeyse bütün dersler sıralanmıştır.

19. soru, "Üniversiteye gidecek olan yakınlarınıza|öğrencilerinize bu bölümü tavsiye eder misiniz?" sorusuydu. 77 kişiden 52'sinin etmeyeceklerini, bunun da nedeninin iş bulma sıkıntısı olduğunu söyledi. Ancak "etmem" diyenler peşi sıra, "tavsiye edecekleri kişilerin iş bulma kaygıları yoksa maddi olarak rahatlarsa, akademik kariyer yapmayı düşünüyorlarsa veya hobi olarak, ikinci üniversite olarak okumaları için tavsiye edeceklerini akademik olarak devam edecekse, sosyal hayata katkı sağladığı için ve de insanın kendini geliştirmesi için iyi bir bölüm olduğundan bu bölümü tavsiye edeceklerini belirtmişlerdir. "Tavsiye ederim" diyen 25 kişinin 2'si bölümü tavsiye ediyor, ama üniversiteyi tavsiye etmiyor. Geriye kalanlar da "tavsiye ederim" demelerine rağmen, öğretmen olarak atanmanın zor ve iş alanının kısıtlı olduğunu belirtip yine de tavsiye edeceklerini söylemişlerdir.

20-23. sorular toplumumuzda felsefeye ilişkin önyargılarla ilişkili sorulardı. 77 kişiden 74'ü, önyargılarla karşılaşttklarını belirtmişler ve bu önyargıları "ateist olmak", "akıl sağlığını kaybetmek", "felsefenin anlamsız olması", "işe yaramaması" olarak sıralamışlardır. 71 kişi bu önyargılara katılmadıklarını söylemişlerdir. Bir kişi bu konu üzerine düşünmediğini belirtmiş, diğerleri iş bulma sıkıntısının, pratikte "bir işe yaramadığının" haklı bir eleştiri olabileceğini düşündüklerini ifade etmişlerdir. Bir kişi de, "felsefecilerin felsefeyi doğru bir şekilde topluma anlatmadığını, bu nedenle, bu önyargıların bir türlü yıkılmadığını ve bu anlamda bu önyargılarda felsefecilerin de payı olduğunu düşündügünü" söylemiştir. "Toplumdaki önyargılardan etkilendiniz mi?" sorusuna, 67 kişi "etkilenmedim" cevabını verirken geriye kalan on kişi "ilk başta etkilendim" cevabını vermiştir. Felsefe mezunlarının karşılaştkları önyargılara nasıl tepki verdikleri de bu önyargılarla mücadele açısından önemli bir soruydu. Bu soruya genel olarak "önyargıların bilgisizlikten kaynaklandığını anlatmaya çalıştıklarıı”, "ilgili olanları aydınlattıklarını", "alay konusu olunca gülüp geçtiklerini", "felsefeyi savunduklarını", "hayata bakış açılarını felsefenin kazandırdığını anlatmaya çalıştklarını" ama savunmalarının yetersiz olduğunu anlayınca "tepkisiz kaldıklarını" ifade etmişlerdir.

Mezunlara bu bölümden mezun olduktan sonra felsefeyle uğraşmaya devam ediyor musunuz sorusu sorulduğunda, ettiğini söyleyen 41 kişiden 9'u felsefe grubu öğretmenliği ve rehber öğretmenlik yaptı̆̆ını, 3 kişi yüksek lisans yaparak devam ettiğini, geriye kalanların ise felsefe çalışmalarını takip edip, dergi, haber, gazete ve felsefe kitapları okuduklarını belirtmişlerdir. 36'sı ise "etmiyorum" yanıtını vermiştir.

Son soru, "Şu anda felsefe değil de başka bir bölüm okumayı diler miydiniz?" sorusuydu. 29 kişi felsefe okuduğundan pişman olmadığını belirtmiş ancak felsefenin yanında sosyoloji, psikoloji, veya sınıf öğretmenliği okumuş olmayı 
istediğini söylemiştir. 12'si psikoloji, 7'si sınıf öğretmenliği, 6'sı hemşirelik, eczacılık, fizyoterapi, sağlık bilimleri; 4 kişi din kültürü veya ilahiyat; 3 kişi psikolojik danışmanlık ve rehberlik; 2 kişi edebiyat, 3 kişi de "sadece daha kolay atanan bir bölüm olabilir" demişlerdir, ancak meslek belirtmemişlerdir. 2 öğrencinin cevabı yoktur. Geriye kalanlar ise Türkçe öğretmenliği, beden eğitimi, özel eğitim, okul öncesi, sosyal hizmet, radyo televizyon sinema veya konservatuar demiş̧ir. Mezunlardan birisinin ifadesi genel eğilimi özetlemektedir: "Başka bir bölüm okumuş olmayı dilemezdim. Her zaman 'iyi ki' dedim, gelirken istemedim ama bitirince 'iyi ki' dedim. İşsiz kalsam da, hiçbir zaman bir işim olmasa da, para kazanamasam da, hani ileride çocuğumu ne seviyede eğitebileceğimi en azından kafamda kurguladım diyebilirim yani bu da bölümümün bana katkısı diyebilirim."

\section{Tartışma ve Sonuç}

Felsefe doğal dünyada kendimiz ve yerimiz üzerine temel sorularımızdan ve düşünmelerimizden oluşan bir disiplindir. Öğrencilerin bir kısmı bu sorulara yanıtlar bulma amacıyla felsefeye gelirler. Ancak toplumumuzdaki felsefeye ilişkin olumsuz önyargılar, öğrenciler daha felsefeyle tanışmadan onların bu hevesini boğar. Heveslerinin yarıda kalmasının yanı sıra, bir de "ben ne olacağım, mezun olduktan sonra ne iş yapacağım" kaygısı baş gösterir. Felsefe mezunları arasında yapılan bu çalışma kısa vadede, felsefe bölümü mezunlarının bu ekonomik şartlar altında, başka bölümlerden mezun olanlardan daha fazla oranda dezavantaja maruz kalmadıklarını göstermeyi amaçlamıştr. Hatta felsefe disiplininin olaylara farklı açılardan bakabilme, sistematik düşünebilme, argümente edebilme, argümanlara dayalı ve sistematik yazma gibi kazanımları, mezunlarını özel ve iş yaşamlarında başarılı kılabilmekte olduğunun verilerle ortaya konulması hedeflenmiştir.

Türkiye Felsefe Kurumu ve UNESCO Türkiye Milli Komisyonu (UTMK Felsefe İhtisas Komitesi) birlikte felsefe eğitimi konusunda ulusal bir strateji belirlenmesi gerektiğini belirtmiş ve bu stratejinin temel amaçlarını da şöyle sıralamıştır: "Ülkemizin insanlarına olan bitenler üzerine felsefi/etik bilgilere dayanarak kendi adına düşünmelerine yardımcı olmak"; "her düzeydeki felsefe eğitiminin bu amaçlara ulaştırma umudunu veren bir şekilde gerçekleştirilmesine katkıda bulunmak"; "yaygın felsefe eğitimini geliştirmek, bunu için TRT'de güncel konular üzerine düzenli felsefe programlarının yapılmasını sağlamak ve bu programların hazırlığını yapmak"; "insan haklarının felsefi araştırmalarına teşvik etmek ve bu hakların felsefiletik eğitimini geliştirmek" vb. (Tepe, 2014, s. 26). Bu plan hayat geçirildiğinde, eleştirel düşünen, sorgulayan ve vatandaşlık bilinciyle davranan bireylerin yetişeceği açıktır.

Bunun yanı sıra, felsefe bölümü öğrencilerinin içerisinde yaşadıkları toplumun sorunları görebilmelerini istiyorsak, üniversite lisans düzeyindeki felsefe eğitiminin ana amaçlarının neler olması gerektiğini sormalıyız. Bu soruya Kuçuradi (2014, s. 18), kısaca şu yanıt vermektedir: Üniversite düzeyinde felsefe eğitimin ana amaçlarından biri, "kişilerin problem görme yeteneğini -teorik olduğu kadar yaşamdaki aykırılıkları görme yeteneğini- geliştirebilmelerine yardımcı olmak ve görülen problemle ilgili soru sorabilmek, onu çözümleyebilmek, sorulan soruya cevap verebilmek ve bu cevabı sistematik bir şekilde dile getirebilmek için gerekli donanımı sağlamaktı"”.

Ancak, mevcut bir problemi ve arka planını görebilmeyi sağlayan felsefe eğitimi, felsefe tarihini öğretmekten ibaret olmamalıdır. Bunun yerine problem odaklı ve eleştirel bir felsefe eğitimi verilmelidir (Kuçuradi, 2014, s. 19). Ayrıca herhangi bir problemi öğrencilerin nasıl etraflıca tartş̧acağı öğretilmelidir. Felsefi bir tartşma, kavramlaştırmayla ve soyutlamayla gerçekleşebilir. Bu tartı̧̧malarda, kavramlar isteyenin istediği tarafa çekilmemeli, kavramlar ve argümanlar açık ve seçik hale getirilmeli ve kavramların sömürülmesi engellenmelidir. Böyle bir tutumun engellenmesi ise "kavram, düşünme ve anlam ilişkisinin metafizik spekülasyonlardan uzak bir biçimde kurulması, dile getirilen yargıların doğruluk değerlerinin ölçülebilir, bir başka deyişle, yargıların epistemik açıdan doğrulanabilir ya da yanlışlanabilir olmasıyla" (Yağanak, 2009, s. 345) mümkün olabilir. Oysa, tartş̧ma programlarında, tutarlı argümanlarla tartş̧ma yerine demagoji yapıldığını görmekteyiz. Bu tür programlarda kavramların içi boşaltıımış bir şekilde kullanılmaktadır. Taşkın'ın araştırmasında ortaya koyduğu gibi, argümanlarla tartş̧ma yetisi geliştirememe yalnızca felsefe mezunlarının değil, diğer disiplinlerden mezun olanların da ciddi sorunudur. Özellikle evrim kuramıyla ilgili tartı̧̧malarda fen bilgisi öğretmenlerinin iddia, veri ve gerekçe arasında bağ kuramadıkları tespit edilmiştir (Taşkın, 2013, s. 200). Bu bağın kurulabilmesi felsefe disiplini için olmazsa olmazdır.

Yapılan görüşmelerde mezunların da şikayet ettiği konulardan olan ezberci eğitimin önüne geçilmeli ve felsefe eğitimi argüman kurabilme ve değer yargıları geliştirme üzerine olmalıdır. Felsefe eğitiminin felsefe tarihine ve filozoflara ilişkin bilgi kazandırmaktan çok, felsefe yapmayı amaçlaması gerekir. Felsefe yapmak eleştirel düşünmeyle başlar. Bunun yanı sıra etik eğitimi de önemlidir. Öğrenciler etik bir sorumluluk duygusuyla hareket etmeli, sorunlara bu bakış açısıyla bakmalıdırlar. Bu sayede, felsefe ülkemizdeki ve dünyadaki barışa katkı sağlayabilecektir.

Benzer şekilde Kuçuradi, felsefenin toplumsal sorunları görebilme ve sorunları doğru adlandırarak, doğru çözümler bulabilme yetisini öğrencilere kazandırma işlevinin olması gerektiğini hatırlatıyor. Örneğin, idam cezasının geri gelmesi

| Kastamonu Eğitim Dergisi, 27(4), 2019| 
üzerine yapılan tarţşmalar, konunun ve bu cezanın insan hakları bağlamında ele alınmadığını gösteriyor. Bu da idam cezasının geri geldiği ve gelmesinin tartı̧̧ıldığı ülkelerde felsefe eğitiminin yetersizliğini gözler önüne seriyor (Kuçuradi, 2014, s. 18).

Bu çalışma felsefe müfredatının mezunlar üzerindeki etkisini görmeyi de amaçlamıştır. Müfredatın eksikliklerine veya mezunların iş yaşamları üzerindeki katkısına ilişkin detaylı sorular sorulmamıştı. Ancak verilen yanıtlardan da anlaşıldı̆̆ı üzere mevcut müfredat ve seçmeli dersler üzerine daha ayrıntılı çalışmalar yapılması gerektiği ortaya konulmuştur. Sara Çelik (2014) üniversitelerdeki eğitimin ve özellikle de felsefe eğitiminin amaçlarıyla müfredatın örtüşmesi gerektiği üzerinde durmaktadır. Çelik, üniversitelerin bilimsel araştırma merkezleri olarak öncelikli hedefinin toplum ve insanlık adına ilerlemeyi sağlayacak araştırmalara öncelik vermesi gerektiğini tespit eder. Ancak bunun yanı sıra mesleki eğitim de önemlidir. Öğrenciler mezun olduktan sonra istihdam edildiklerinde çalışmalarını yapabilmeleri için gerekli donanıma sahip olmalıdırlar. Dolayısıyla, felsefe bölümleri de yetiştirdikleri öğrencilerin, ileriki mesleki yaşantılarında gerekli donanıma sahip olmalarını sağlamakla yükümlüdür. Felsefeye giriş ve felsefe tarihi dersleri, bütün felsefe bölümü müfredatlarında zorunludur. Bunun yanı sıra, öğretmen olabilmenin yasal bir koşulu olan on alţ̧̧ar kredilik sosyoloji ve psikoloji dersleri de programlar da bir tür zorunlu dersler olarak yer almaktadırlar (Çelik, 2014, s. 67, 72).

Çelik, programlarda bulunan bu derslerin yanı sıra, felsefi ve etik düşünmeye yönelik uygulamalı derslerin de konulması veya varsa sayısının arttırıması gerektiğini belirtmektedir. Bu derslerin amacı etiğin bilgisini vermek değil, etik düşünme refleksi kazandırmak olmalıdır. Bu konuda elbette dersleri veren öğretim elemanlarına büyük iş düşmektedir. Öncelikle onların eleştirel düşünebilmeleri, etik bir tutuma sahip olmaları gerekir (Çelik, 2014, s. 75-6).

Zamanla felsefe bölümleri mezunlardan alınan geribildirimlerle kendilerini yenileyip, geliştirebilirler. Çalışmanın uzun erimli etkisi, felsefeye dair olumsuz önyargıların zamanla kırılması olabilir. Bu sayede felsefe bölümünü tercih eden öğrenciler, daha bilinçli ve isteyerek bu bölümü tercih edebilirler.

Bu çalışmayla birlikte, temel bilimlerin ve klasik disiplinlerin önemi vurgulanacağından, çalışmanın sonuçları, yalnızca felsefe bölümünü değil, Fen Edebiyat Fakültelerine bağlı diğer bölümleri de ilgilendirmektedir.

Bu görüşmelerde çıkan sonuçlara göre toplam mezun sayısının yarısından fazlası gerek bölümle ilgili alanlarda gerekse bölüm dışı alanlarda çalışmaya devam etmektedirler. Çok az sayıda mezunun yüksek lisans eğitimine devam ettiği görülmektedir. (Bu araştırmanın tamamlanmasının ardından Kastamonu Üniversitesi Felsefe Bölümü'nde yüksek lisans programı açılmıştı; programın açılmasıyla sonraki mezunların yüksek lisans eğitimine yöneliminin artması beklenmektedir.)

Mezun olduktan sonra yaptkkları işler genellikle ücretli öğretmenlik, rehber öğretmenliği, rehabilitasyon merkezleri alanlarında yoğunluk göstermiştir. Mezun olduktan sonra mezunların çoğu iş bulmakta zorlandığını, bir kısmı da zorlanmadığını belirtirken hiç iş aramadığını belirtenler de olmuştur.

Mezunların çoğu felsefe okumanın dezavantajını gördüğünü söylemiş fakat burada da belirtelim ki bu dezavantajının nedeni toplumun felsefeye olan ön yargıları ve sınırlı iş imkanıdır. Onun dışında bazı mezunlar avantajını gördüğünü, bazıları hem dezavantajının hem de avantajının olduğunu, bazı mezunlar ise felsefeyi hayatına yerleştirmediğini belirterek iş bulmada ya da sınava hazırlanırken bir etkisinin olmadığını söylemişlerdir.

Felsefe okumanın mezun olduktan sonra hayatlarına kişisel anlamda çok şey kattı̆ını hemen hemen bütün mezunlar söylemişlerdir. Bakış açılarının geliştiğini, kendilerini daha iyi ifade edebildiklerini, özgün düşünebildiklerini, sorgulayabildiklerini söylerken bu anlamda felsefe eğitiminin kısmen de olsa başarılı olduğunu söyleyebiliriz. Ama mezunlar genellikle iş imkanlarının sınırlılı̆ından söz etmiş toplumun felsefeye bakışının olumsuz olmasından kaynaklı sıkıntılar çektiklerini belirtmişlerdir.

Araştırmaya katılanların 79'unun kadın, yalnızca 8'inin erkek olduğu göz önünde bulundurulması gereken bir diğer husustur. Mezun kadınlardan bazıları evli veya nişanlıdır. Kendilerini ev kadını olarak tanımlamakta ve iş arama girişiminde bulunmamaktadırlar. Araştırmanın sonucunda ortaya çıkan bu durum, toplumsal cinsiyetin ev dışında çalışma üzerinde halen ne denli etkili olduğunu da işaret etmektedir. Kadınların özellikle ülkemizde dışarıda bir işte çalışması "isteğe bağı" veya "keyfi" algılanmaktadır. Erkekler içinse, iş aramak, profesyonel bir işte çalışmak, evi geçindirebilecek bir gelir elde etmek neredeyse zorunlu görülmektedir. Toplumun erkeklerden ve kadınlardan farklı beklentileri olması, öğrencilerin baştan felsefe okumayı seçip seçmemeleri aşamasında etkili olmaktadır. Öğrencilerin üniversite sınavı sonrası bölüm tercihlerinde toplumsal cinsiyetlerinin ne derece belirleyici olduğuna yönelik çalışmalar yapılmıştır (Örneğin, bkz. Parlaktuna, 2010). Felsefe mezunlarının cinsiyetleri, bölüm seçimleri ve mesleki beklentileri arasındaki ilişkiye ilişkin daha özel araştırmalar yapılmalıdır. 
Esasen, felsefe lisans programı mezunlarının istihdam sorunu fen edebiyat fakültelerinin diğer bölümlerinden mezun olanların istihdam sorunundan bağımsız değildir. Fizik, kimya, biyoloji, tarih, coğrafya bölümlerinden mezun olanlar da, Milli Eğitim Bakanlığı'na bağlı okullarda öğretmen olmak için merkezi sınavlarda yüksek başarı gösterseler bile, kontenjanlar çok az olduğu için atanamamaktan şikâyet etmektedirler.

Özbek (2014, s. 234) "Yükseköğretimde Felsefe Eğitimi Çalıştayı"nda felsefe lisans programlarının kontenjanlarının akademi dışında siyasi kaygılarla artıııldı̆ını ifade etmiştir. Felsefe bölümlerindeki öğretim üyelerinin bu kadar çok felsefe mezunun ne iş yapacağı sorununu çözemeyeceğini, "sorunu çözmek için alınan önlemlerin de sorunun bir parçası olduğunu" belirtmiştir. Özbek bu anlamda haklıdır. Örneğin felsefe mezunlarının felsefe grubu öğretmeni olabilmeleri için almaları gereken pedagojik formasyon eğitimi her yönüyle sorunludur ve Özbek'in dediği gibi, bu politikayı sorgulamak gerekmektedir. Bu sorun salt felsefe bölümlerini değil, fen edebiyat fakülteleri bünyesindeki tüm bölümleri ilgilendirmekledir. Ayrıca formasyon almış fen edebiyat fakültesi mezunlarının Milli Eğitim Bakanlığı bünyesinde görev alabilmeleri de, ilgili fakültelerden mezun olanlarının sayısının, atanma kontenjanlarııın kat kat fazlası olduğundan düşük bir ihtimaldir. Aynı sorun eğitim fakültesi mezunlarının da sorunudur. Dolayısıyla, bu sorunun çözümü çok daha bütünlüklü bir eğitim politikasıyla mümkündür.

Ancak genel olarak fen edebiyat fakültelerinin diğer bölümlerinden farklı olarak, felsefe mezunlarının istihdamı sorununun, felsefenin gündelik yaşamdan kopuk olduğu önyargısıyla bağlantılı olduğu unutulmamalıdır. Felsefenin doğrudan veya dolaylı olarak yaşamla, insanla, doğayla ve toplumla ilgisini gösterebilmek felsefecilerin görevidir. Mezunlardan birinin ifadesini burada tekrar yinelemek gerek: "felsefecilerin felsefeyi doğru bir şekilde topluma anlatmadığını, bu nedenle, bu önyargıların bir türlü yıkılmadığını ve bu anlamda bu önyargılarda felsefecilerin de payı olduğunu düşünüyorum." Bu çalışmanın amacı da, daha önce belirtildiği gibi, felsefenin gündelik yaşamda işe yararlılı̆ını ortaya koyabilmektir ve bu anlamda toplumumuzdaki mevcut önyargılarla mücadele edebilmektir. Felsefecilerin Israrla, felsefenin Aristoteles'in, Kant'ın fikirlerini ezberlemek demek olmadığı, insan ve yaşamın bütününe dair doğru soruları sormayı, sorunları doğru bir şekilde kavramsallaştrmayı ve sorunların ancak doğru kavramlarla doğru bir şekilde sorulduğunda çözüm bulunabileceğinin altını çizmesi gerekmektedir. Bu yaklaşımın yaygınlaşması, felsefecilerin istihdam sorununu elbette çözmeyecektir ama yarışa diğer lisans programlarından mezunlarla en azından eşit bir yerden başlayabileceklerdir.

Felsefe eğitimi aldıktan sonra ortaya çıkan bu değişmeler kısmen eğitimi alan kişiyle ilgilidir. Diğer bir ifadeyle, değişimlerin etki dereceleri öğrencinin eğitimden ne almak istediğine bağlıdır diyebiliriz. Öyle ki felsefe zaten bireyi tanımaya, araştırmaya, düşündürmeye, sorgulamaya, hazır duruma getirmeye odaklı bir alandır. İnsanı konu edinmektedir ve bireyin aslında yaşam boyu sürdürmesi gereken bir eğitimdir felsefe. Kişiler felsefe lisans programlarına salt bir diploma edinme süreci olarak bakmazlarsa, felsefenin sunduğu firsatların farkında olur ve onları birer kazanıma dönüştürmeye çalışırlarsa, başarılı olacaklardır. Böyle olduğunda zaten istihdam alanları genişleyerek iş olanakları felsefe üzerimde bir dezavantaj olmaktan kurtarılacaktır. Bununla birlikte daha yetkin daha çok sorgulayan, farkındalık yaratan bireyler toplumda yerlerini alacaklardır.

Kastamonu Üniversitesi Felsefe Bölümü başkanı Yavuz Unat felsefe bölümü mezunlarının istihdamına özel bir önem vermektedir. Mezunlarının toplumla aydınlar arasında bir köprü görevini, gördüğünü belirten Unat (2014, s. 106), felsefe bölümü mezunlarının "felsefeci" unvanı aldıklarını, felsefe alanına ilişkin edindikleri bilgi birikimiyle ve kazandıkları tartışma ortamlarında savlar geliştirebilme ve savlarını savunabilme becerileriyle öğretmenlik ve akademisyenlik yapabileceklerini belirtmiştir. Ayrıca, mezunlardan bazılarının Kültür bakanlığı ve diğer bakanlıkların eğitim ve kültür ile ilgili birimlerinde, TRT ve diğer yayım kuruluşlarında, üniversitelerde, kamu kuruluşları ile özel kuruluşların eğitim, kültür, insan ilişkileri, planlama ve değerlendirmeyle ilgili birimlerinde çalışma olanağı bulduklarını ifade etmiştir. Bunun yanı sıra, yazma üzerine kendilerine verilen eğitimi geliştiren öğrencilerin, yazarlık yaptı̆̆ıı da eklemiştir (Unat, 2014, s. 107)

Unat'ın girişimiyle, 2012 yılından itibaren Kastamonu Üniversitesi Felsefe Bölümünde öğrencilerin iş olanaklarını arttırmak amacıyla isteğe bağlı staj uygulamasını başlatılmıştr. Bu uygulamayla, öğrenciler stajlarını, Kastamonu Üniversitesi'ne bağlı uygulama birimlerinde, çeşitli özel eğitim ve sağlık kuruluşları da, Valilik ve Belediye vs. gibi devlet kuruluşlarında ve uygun görülen özel kuruluşlarda, eğitim ve rehberlik danışmanlığı gibi konularda yapabilmektedirler. (Unat, 2014, s. 107)

Çotuksöken'in (2014, s. 1-17) ifade ettiği üzere, son bir kaç yıldır, profesyonel yaşamdaki başarının salt mesleki eğitimle olmayacağı saptandı ve temel bilimlerin işlevi ve önemi yeniden konuşulmaya başlandı. Felsefe eğitiminin eleştirel, yaratıcı ve özenli düşünen, olup bitenler arasında bağlant kuran, olup bitenler arasındaki neden-etki ilişkilerini doğru bir biçimde saptayan insanların yetişmesine yardımcı olduğu düşünüldüğünde, felsefeye halen ve bugün belki de geçmişte olduğundan daha fazla ihtiyaç vardır. 
Araştırmanın sonuçları, hem halihazırda felsefe okuyanları, hem felsefe bölümünü tercih etmeyi düşünen lise öğrencilerini, hem felsefe bölümü öğretim üyelerini, hem de mezunları ilgilendirmektedir. Yalnızca Kastamonu Üniversitesi Felsefe Bölümü öğretim üyeleri değil, diğer üniversitelerdeki felsefe bölümü öğretim üyeleri de bu çalışmanın verilerinden yararlanacaklardır ve sağlanan veriler ışığında programlarında gerekli değişikliklere gidebileceklerdir. Daha da önemlisi, felsefe ve temel bilimlerin öneminin alt çizilmiş olacaktır. Henüz üzerinde hiç çalışılmamış olan bu konunun çalışııması, ileride bu alanda çalışacak olan bilim insanlarına da yol gösterici olacaktır.

\section{Kaynakça}

American Philosophical Association. (2002). A non-academic career? Erişim adresi: https://www.apaonline.org/page/nonacademic

American Philosophical Association. (2008). Statement on the role of philosophy programs in higher education. Erişim adresi: https://www.apaonline.org/page/role_of_phil

Anders, G. (2016, 11 Eylül). Good news liberal-arts majors: Your peers probably won't outearn you forever. The Wall Street Journal. Erişim adresi: https://www.wsj.com/articles/good-news-liberal-arts-majors-your-peers-probably-wont-outearn-you-forever-1473645902

Avrupa Yükseköğrenim Komisyonu. (2012). Quality and relevance in higher education. Erişim adresi: http://ec.europa.eu/education/policy/higher-education/quality-relevance_en

Balcı, A. (2001). Sosyal bilimlerde araştırma-yöntem, teknik ve ilkeler. Ankara: Pegem A Yayıncılık.

Çelik, S. (2014). Üniversitelerde felsefe lisans eğitimi. T. Ketenci ve C. M. Tosun (Yay. Haz.). Yükseköğretimde felsefe eğitimi içinde (s. 67-79). Ankara: Türkiye Felsefe Kurumu.

Çotuksöken, B. (2014). Felsefe mezunlarının istihdamı. T. Ketenci ve C. M. Tosun (Yay. Haz.). Yükseköğretimde felsefe eğitimi içinde (s. 111-125). Ankara: Türkiye Felsefe Kurumu.

Çotuksöken, B. (2016, 12 Mart). Temel bilimler zihni mesleğe hazırlıyor. Hürriyet Gazetesi. Erişim adresi: http://www.hurriyet. com.tr/egitim/temel-bilimler-zihni-meslege-hazirliyor-40067644

Erdem, H. H. (2014). “Öğretmenlik Sertifika Programı ve Felsefe Bölümü Mezunlarının İstihdam Sorunu ”. T. Ketenci ve C. M. Tosun (Yay. Haz.). Yükseköğretimde felsefe eğitimi içinde (s. 125-129). Ankara: Türkiye Felsefe Kurumu.

Horizon 2020 - Work Programme 2014-2015. (2015). Science with and for Society, (European Commission Decision C (2015) 2453, 17 Nisan. Erişim adresi: https://ec.europa.eu/research/participants/data/ref/h2020/wp/2014_2015/main/h2020wp1415-swfs_en.pdf

İnam, A. (2009). "Felsefe Mezunlarının Sorunları”. Felsefe Yazın. 15 (s. 66-67).

Kafadar, O. (2000). Türkiye'de kültürel dönüşümler ve felsefe eğitimi, İstanbul: İz Yayıncılık.

Karakuş, R. (ed.) (2011). III. Felsefe çalıştayı: Değişen üniversite ve felsefe eğitimi. Sakarya: Sakarya Üniversitesi Yay.

Ketenci T. ve Tosun C. M. (ed.) (2014). Yükseköğretimde felsefe eğitimi. Ankara: Türkiye Felsefe Kurumu.

Kılıç, Y. (2014). Felsefe bölümlerinde lisans eğitimi. T. Ketenci ve C. M. Tosun (Yay. Haz.). Yükseköğretimde felsefe eğitimi içinde (s. 55-67). Ankara: Türkiye Felsefe Kurumu.

Kuçuradi, I. (2014). Yükseköğretimde felsefe eğitimi. T. Ketenci ve C. M. Tosun (Yay. Haz.). Yükseköğretimde felsefe eğitimi içinde (s. 17-21). Ankara: Türkiye Felsefe Kurumu.

Light, J. (2011, 4 Ocak). The best and worst jobs 2011. The Wall Street Journal. Erişim adresi: https://www.wsj.com/articles/SB10 001424052748704723104576062173458318658

Needleman, S. E. (2010, 5 Ocak). The best and worst jobs 2010. The Wall Street Journal. Erişim adresi: https://www.wsj.com/ articles/SB10001424052748703580904574638321841284190

Parlaktuna, i. (2010). Türkiye'de cinsiyete dayalı mesleki ayrımcılığın analizi. Ege Akademik Bakış. 10:4 (Ekim), (s. 1217-1230).

Özbek, S. (2014) Üniversitede felsefe bölümlerinin geleceği. T. Ketenci ve C. M. Tosun (Yay. Haz.). Yükseköğretimde felsefe eğitimi içinde (s. 233-239). Ankara: Türkiye Felsefe Kurumu.

Stanford University, Philosophy Department. (2018). Why philosophy? Erişim adresi: https://philosophy.stanford.edu/about/ why-philosophy

Starkie, E. G. (2008). Core elements of the European (higher) education policy: Market-driven restructuring or impetus for intercultural rapprochement? International Review of Education, 54 (3/4), 409-425. Erişim adresi: https://eric.ed.gov/?id=EJ801024

Taşkın, Ö. (2013). Pre-service science teachers' acceptance of biological evolution in Turkey, Journal of Biological Education, 47:4, 200-207.

Tepe, H. (2013). “UNESCO Türkiye Milli Komisyonu ve üniversitelerde felsefe eğitimi. T. Ketenci ve C. M. Tosun (Yay. Haz.). Yükseköğretimde felsefe eğitimi içinde (s. 25-28). Ankara: Türkiye Felsefe Kurumu. 
Unat, Y. (2014). Kastamonu Üniversitesi felsefe bölümü ve felsefe bölümlerinde sorunlar ve çözüm önerileri. T. Ketenci ve C. M. Tosun (Yay. Haz.). Yükseköğretimde felsefe eğitimi içinde (s. 105-111). Ankara: Türkiye Felsefe Kurumu.

University of Kentucky Department of Philosophy (2018) Where can philosophy take me?. Erişim adresi: https://philosophy. as.uky.edu/where-can-philosophy-take-me

University of North Carolina at Chapel Hill Department of Philosophy (2014). Why major in philosophy?. Erişim adresi: http:// philosophy.unc.edu/undergraduate/the-major/why-major-in-philosophy/

University of Florida Department of Philosophy (2018). What is the use of philosophy?. Erişim adresi: http://www.phil.ufl.edu/ ugrad/whatis/whatuse.html

University of Florida Department of Philosophy (2018). Valuing philosohy education. erişim adresi: http://www.phil.ufl.edu/ events/value.html

Willamette University, Department of Philosophy (2018). What can I do with a philosophy major?. Erişim adresi: http://www. willamette.edu/cla/philosophy/practical/

Yağanak, Eray. (2009). Felsefe öğretimi açısından kavram, anlam ve anlama ilişkisi, Uluslararası felsefe eğitimi kongresi: küreselleşme sürecinde eğitim sorunlarının felsefi boyutu içinde. H. R. Açar (Editör). (s. 345-350). Ankara: Gözde Matbaacılık. 